\title{
"Controlling for what?" \\ Folk economics, legal consciousness and the gender wage gap in the United States
}

\author{
Dan Hirschman \\ daniel_hirschman@brown.edu
}

\begin{abstract}
Studies of the political power of economic knowledge have tended to foreground the role of causal claims in the form of grand theories or more narrow findings produced by experimental methods. In contrast, scholars have paid relatively little attention to the role of economic experts' descriptions. This article highlights one category of influential, quantitative descriptive claim: stylized facts. Stylized facts are simple empirical regularities in need of explanation. Focusing on the example of the gender wage gap in the United States, this article showcases how stylized facts travel into political debates, and how the choices made in characterizing an aspect of economic life (such as controlling for full-time work, but little else) interact with social movement activism, and folk understandings of economic life shaped by legal consciousness. The gender wage gap was first calculated in the 1950s, but did not take on special importance until the 1960s1970s when feminists rallied around the statistic as a useful aggregate measure of women's economic disempowerment. Academics soon followed, and sociologists and economists began to publish studies documenting trends in the gap and trying to account for its sources. The comparable worth movement of the 1980s explicitly argued that the wage gap resulted from occupational segregation and the devaluation of women's work. As that movement faltered in the late 1980s, the gender wage gap became increasingly understood through the lens of women's choices and tradeoffs between work and family, and occupational segregation dropped out of the narrative, even as academics documented the persistent importance of segregation in explaining the remaining gap. Throughout this period, the gap was frequently misunderstood or misrepresented as reflecting the narrow sort of same-job, different-pay discrimination made illegal by the 1963 Equal Pay Act, adding confusion to the public debate over women's economic position. These dynamics showcase how technical choices made in the identification of stylized facts, such as statistical controls, are simultaneously deeply political choices.
\end{abstract}

\section{Acknowledgments}

I thank Laura Adler, Cléo Chassonnery-Zaïgouche, Kira Lussier, members of the Brown University workshop on Work, Organizations, and the Economy, and participants at the 2021 HOPE Conference on Women and Economics for comments on prior versions of this manuscript. 


\section{Introduction}

Each year, the National Committee on Pay Equity (NCPE) announces a new "Equal Pay Day." In 2021, NCPE tells us that Wednesday, March $24^{\text {th }}$ represents "how far into the year women must work to earn what men earned in the previous year." (NCPE 2021) The NCPE bases its moving calendar on measurements of the "gender pay gap" (also called the gender wage gap), typically defined as the ratio of women's average earnings to men's, among those working full-time. Right now, the pay gap sits around 82 cents on the dollar; put differently, the average earnings of fulltime employed women are about 18\% lower than the average incomes of full-time employed men (see Figure 1). This stylized fact also circulates in intersectional form, showcasing the even-lower wages paid to Black, Latina, and Native American women (see Figure 2). The gender pay gap figures prominently in debates around inequality. Along with the NCPE, progressive organizations like the Economic Progress Institute and the American Association of University Women (AAUW) routinely publish explainers with titles like "The Simple Truth About the Gender Pay Gap" foregrounding the apparent obviousness of the gap and its stubborn refusal to close (AAUW 2020). These publications summon ritualized counter-performances, as each year the conservative American Enterprise Institute and its fellow travelers offer rebuttals with titles like "The Gender Wage Gap Myth" (Hoff Sommers 2014).

This article explores how debates around economic inequality between men and women came to focus on this particular stylized fact, and how that fact circulates within academic, policy, and public debates. How did the gender pay gap come to be the sort of thing that can have a "simple truth" or a status as "myth"? What sorts of politics does the gender pay gap enable or frustrate? What can our shifting interpretations of the gap tell us about our understandings of men and women's places in economic life, and about ideologies of agency and structure?

\section{Women are paid less than men}

On average, women in the U.S. make $18 \%$ less than men. ${ }^{1}$

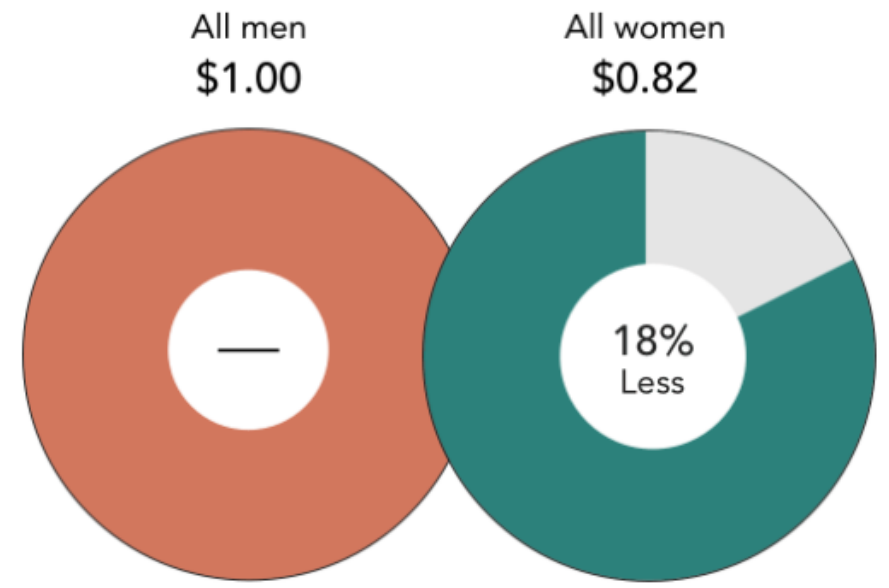

Figure 1: Aggregate gender wage gap. From LeanIn.Org (2021). The footnote cites Hegewisch and Tesfaselassie (2020). 


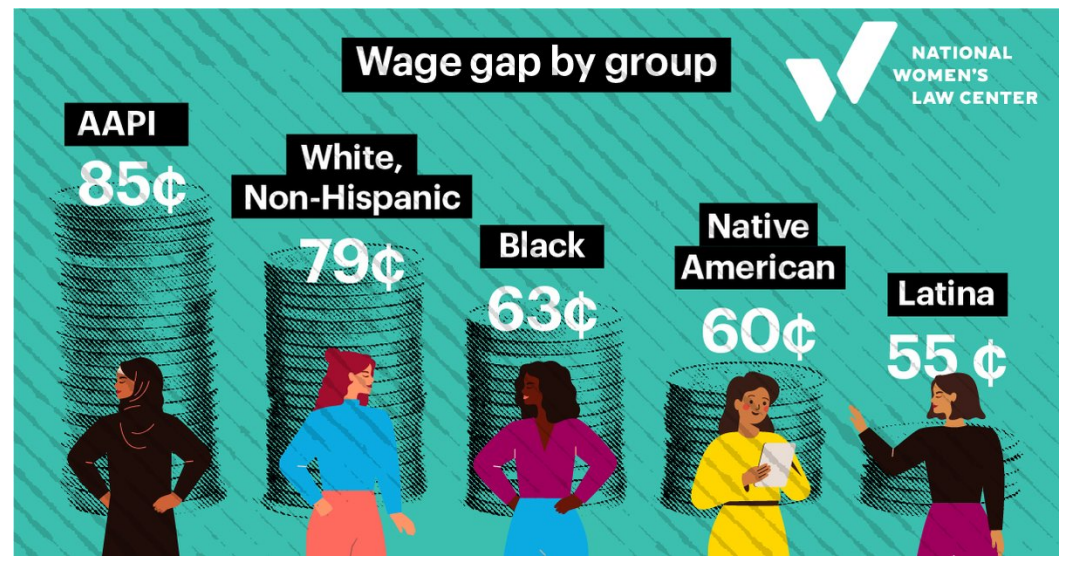

Figure 2: Intersectional gender wage gap. From National Women's Law Center.

This article is part of a larger project attempting to understand the role of stylized facts in the production and circulation of economic knowledge (see Hirschman 2016). Attempting to formalize the folk concept used by economists since the 1960s, I define stylized facts as empirical regularities in need of an explanation. Stylized facts include trends, correlations, and rates of incidence. The most famous stylized fact, one of the first to be explicitly called out as such, was the observed stability in labor's share of national income (Kaldor 1957). These quantitative descriptions act in economics (and other social sciences) the way that phenomena function in some natural sciences (Hacking 1983). That is, stylized facts are what (some) economic models are built to explain. But, stylized facts do not stay confined to the pages of economics journals. The trends, correlations, and rates identified by academics are capable of traveling out into political discourse (on how facts travel, see Howlett and Morgan 2010). When they travel, stylized facts may serve as a "hinge" (Abbott 2005) bringing researchers and their theories into public discourse and policy conversations. Or stylized facts may travel disconnected from larger bodies of scholarship, instead meeting up with "folk economics" (Swedberg 2018), non-expert understandings that offer alternative explanations of the workings of the economy. In turn, these folk economic understandings may be shaped especially strongly by "legal consciousness" (Ewick and Silbey 1998). As sociolegal scholars have shown, the law has an outsized role in shaping how people believe society ought to work and how it actually works. Social movements may vie to foreground particular stylized facts or particular academic or folk interpretations of those facts which they believe will help to sway public opinion. This article explores these dynamics in the contexts of debates over the extent and causes of the gender wage gap in the United State.

The history of the gender pay gap in the United States begins with debates over women's increasing presence in the paid labor force. I briefly review debates in the late $19^{\text {th }}$ to mid- $20^{\text {th }}$ century, and especially the demands of labor feminists for what later came to be called equal pay for comparable work. In this period, occupational gender segregation was both extreme and widely acknowledged, and feminist activists thus recognized that demands for equal pay for the same work would have relatively little impact on overall economic gender inequalities. Academic debates on gender inequality focused on comparisons within occupations. Data on overall wages 
broken down by gender were scarce; instead, studies focused on particular industries, occupations, or employers.

In the 1960s, both the politics and study of pay disparities shifted. In 1963, Congress passed the Equal Pay Act which enacted a narrow version of labor feminists' demands: only differential pay for the same work would be considered illegal. With the rise of Human Capital Theory and high-quality household survey data, economists and sociologists began to study pay disparities at an aggregate level and to attempt to tease apart the sources of that gap, usually focusing on the relative weights of education, experience, occupation or industry, and discrimination. This research, along with the publications of the Women's Bureau of the Department of Labor, settled on the modern formulation of the gender wage gap which compared the wages of full-time employed men and women, not controlling for anything else.

This choice was not entirely obvious - why control for full-time work when women are much more likely to work part-time? Why not control for hours, given that men employed full-time work, on average more hours? But it stuck. And spread. By the mid-1970s, organizations like the OECD began to compare nations based on their gender wage gap. Discussions of discrimination were framed around the Equal Pay Act, and many studies attempted to rebut the simplistic interpretation of the pay gap as entirely or even largely reflecting unlawful discrimination. Instead, scholars argued that pay differentials came from women's relatively lower levels of education and experience, and from working in lower-paid occupations.

The limits of the Equal Pay Act, and Title VII of the Civil Rights Act of 1964 which banned sex discrimination more generally, became rapidly apparent to a new generation of feminist activists. Throughout the 1960s and 1970s, the gender pay gap stayed stubbornly flat, around 60 cents on the dollar. In the late 1970s, feminist activists frustrated with this apparent stagnation in economic gender equality mobilized around the slogan of "comparable worth." Returning to the demands of labor feminists from the first half of the $20^{\text {th }}$ century, organizations like the NCPE, NOW, labor unions, and allies in the federal government fought to reinterpret Title VII as prohibiting employers from paying lower wages to heavily feminized occupations which otherwise required similar levels of education, skill, and effort. Drawing on employers' own job evaluation systems, scholars and activists tried to prove that women's work was devalued, whether or not the particular occupant of a job was a man or a woman.

The fight for comparable worth yielded some initial successes in the early 1980s before coming to a halt with a shift at the Equal Opportunity Employment Commission under the Reagan administration, and a handful of unsuccessful court cases. Academics continued to publish research about occupational segregation and the promise of comparable worth, but the larger debate on economic gender inequalities shifted. I draw on a hand-coded corpus of newspaper articles to document trends in the invocation and interpretation of the gender wage gap from 1970 through 2014. Absent pressure from the feminist movement, the stylized fact of the gender wage gap became largely delinked from questions of occupational segregation. Instead, debates in the 1990s foregrounded the question of women's "choices", especially surrounding motherhood, childcare, and overwork. Rapid improvements in the gender pay gap during the 1980s flattened out near their current levels. This trend, alongside other transformations, have led scholars to characterize this era as one of an "uneven and stalled" gender revolution (England 2010). While extensive 
occupational segregation persists, motherhood came to occupy the most prominent space in the debate over the enduring gender wage gap. The "folk economics" (Swedberg 2018) of the gender pay gap came to contrast illegal pay discrimination with freely chosen family obligations as the dominant back-and-forth explanatory debate.

At the same time, the gender wage gap continues to be widely misunderstood, as many actors assume it refers to the kind of same-work, different-pay discrimination outlawed by the Equal Pay Act. This misunderstanding is reinforced when the gender wage gap is mobilized in support of policies designed to improve enforcement of the Equal Pay Act (policies which cannot address most of the $18 \%$ gap). And this misunderstanding is exacerbated by the gaps in the household survey-based knowledge infrastructure of labor economics and sociology. Without employeremployee matched data, researchers are not able to definitively answer the question of how much less women are paid than men working in the same jobs.

In the following history, I try to attend simultaneously to the interactions of academics, activists (feminist, labor movement, and conservative), politicians, data, method, and theories. The history of the gender pay gap is at once the history of the development of modern economics and sociology, the shifting fortunes of the American feminist and labor movements, the outsized importance of the law in shaping debates over (in)equality, and dramatic transformations - and non-transformations - in the "arrangement between the sexes" (Goffman 1977). To tell this crisscrossing story, I rely heavily on existing histories of these various movements and dynamics, alongside my own reading of newspapers, academic journals, and political debates as well as a handful of oral history interviews with key scholars. In this effort, I am especially indebted to Laura Garbes and Clare Wan for their research assistance and especially their analysis of discussions of gender and pay disparities in the New York Times, Washington Post, and Wall Street Journal.

\section{Before the Gender Wage Gap}

Before the 1960s, the "gender wage gap" was not yet a thing. Neither government statisticians nor academic social scientists calculated the average earnings of a representative sample of all fulltimed employed women and compare it to that of men. They did not do so in part because the tools needed to do so were simply unavailable. Before the 1940s, household survey data were scarce. The Current Population Survey would not launch until 1948 (although it was based on a survey of unemployment that began in 1940), and the influential Panel Study on Income Dynamics (PSID) did not begin until 1968. Processing those data that existed was difficult and expensive. And theoretical debates did not yet focus on the earnings of individuals, as they would after the rise of Human Capital Theory in economics and stratification research in sociology.

Although the gender wage gap was not yet a recognizable object, let alone a stylized fact, economic gender inequality was well-recognized in the late $19^{\text {th }}$ to mid- $20^{\text {th }}$ century. Debates focused on the question of fair wages for women, and what that implied about women and men's roles in the family and the workplace (Kessler-Harris 2014). ${ }^{1}$ Feminist labor groups mobilized for

${ }^{1}$ For parallel discussions in Britain, see Chassonnery-Zaïgouche (2018). 
equality in the workplace (Cobble 2004), and feminist bureaucrats (such as those in the Women's Bureau of the Department of Labor) published reports and investigations in support of that mobilization (Laughlin 2000). These debates mobilized statistics in support of women's claims for equality, but the statistics available tended to be much narrower, emphasizing specific employers, specific professions, or specific locations. In the 1870s-1930s, the debate focused largely on whether women should work at all, and whether or not they deserved equal pay to men when they did so. Informed by the doctrine of "separate spheres" of family and public life, these debates centered White women and their family obligations, while ignoring the experiences of Black women who were more likely to work outside the home (often as servants for those same White women). Starting in the 1940s, labor feminists expanded the debate to focus both on occupational segregation and comparable worth, with the experiences of World War II making a strong case for women's ability to do traditionally male jobs, and thus laying the groundwork for the argument that traditionally feminine occupations were undervalued compared to those dominated by men.

In this period, some forms of gender pay inequality were stark. For example, a 1906 New York Times story reports on the launch of a campaign for equal pay among schoolteachers in New York City. ${ }^{2}$ While women teachers started at a salary of $\$ 600$ per year with the possibility of pay rising to $\$ 1440$ after 11 years of service, men teachers started at $\$ 900$ with pay rising as high as $\$ 2440$. This kind of explicit pay disparity was legal and typically justified by pointing to men's family obligations, or sometimes their productivity or competitiveness on the labor market.

Although these stark disparities between men and women working in the same jobs for the same employer were perhaps the easiest to document and mobilize against, feminist activists recognized that tackling gender disparities in the workforce would require addressing occupational segregation as well. Most jobs were highly segregated, with women concentrated in a handful of professions like secretary and nurse, and men dominating the rest of the labor market. Women's professions offered lower salaries and fewer opportunities for advancement - for example, in the $19^{\text {th }}$ century, secretaries in large businesses were typically men being groomed for advancement into management. By the early $20^{\text {th }}$ century, the secretarial profession had become a dead-end job for educated women without the possibility of transitioning into a managerial role (Davies 1982).

The labor needs of the wartime economy in World War I put a few dents into the segregated occupational structure. Given the opportunity, women moved into jobs previously occupied by men in large numbers (Kessler-Harris 2014: 28), increasing the salience of the question of equal pay. Why should women welders make less than men welders working in the same factories? Feminist labor activists and their allies in the government, including the Women's Industry Service (which would become the Women's Bureau of the Department of Labor in 1920) pressured for policy changes to force employers to pay women and men equally, the idea of a single "rate for the job" (Kessler-Harris 2014: 35). ${ }^{3}$ This pressure continued through the 1920s and 1930s, uniting

\footnotetext{
${ }^{2}$ New York Times. 1906. "Women Teachers Open Equal Pay Campaign: Interborough Association Demands Same Salary as the Men."

3 The Women's Bureau of the Department of Labor has an interesting and complicated history (see Laughlin 2000). The Bureau served as something of a foothold for the feminist movement inside the executive branch of the U.S. federal government. Its main outputs were research reports and conferences on women's economic position. In the 1920s-1950s, the Bureau was
} 
the efforts of different factions of the feminist movement around the principle of equal pay for equal work with some successes, including equal pay provisions in three-quarters of the industrial codes established by the National Recovery Administration (Kessler-Harris 2014). This pressure ramped up in World War II which followed the same pattern as World War I but to an even greater extent, as millions of women entered into war industries. Somewhat ironically, the push for equal pay in this period also drew in decidedly anti-feminist actors, including some in the labor movement concerned with maintaining occupational segregation by preventing employers from undercutting men's labor with lower-paid women (Kessler-Harris 2014: 77).

Although gender segregation fell during World War II, it remained a stark feature of the American occupational structure. This fact was recognized by feminist activists and academics alike. During and immediately after the war, feminist labor activists began to coalesce around a stronger demand: equal pay for comparable work. That is, they began to demand that women's work be compensated comparably to men's work that required similar effort, skill, risk, experience, etc. In 1943, Z. Clark Dickinson, an economist at the University of Michigan, put the argument starkly:

The slogans "equal pay for equal work" and "the rate for the job" both express too narrowly the real objective of equality of economic opportunity between the sexes, for they concentrate attention too exclusively on the rather few occupations which are common to both sexes in peacetime, or in which women replace men during wartime. An adequate programme of job evaluation attempts to make proper allowance for all compensable factors, to the end that wage rates shall be equitable, not merely within but as between all occupations; and that any significant change, either in the job or in the labour market surrounding it, or both, shall be promptly considered for possible readjustment of the wage. (Dickinson 1943: 711, also cited in Kessler-Harris 2014)

Dickinson's article, titled 'Men's and Women's Wages in the United States", drew on available data to try to assess the level of inequality between men and women's wages. Like most research in this period, Dickinson was limited by the lack of representative national data. Instead, Dickinson focused his account on 25 specific manufacturing industries where data was available. As he noted, "if we seem unduly preoccupied with factory workers, that is only because the data concerning them are most nearly adequate for our analysis" (Dickinson 1943: 703). Reports in this period from the Women's Bureau, like the 1937 publication "Differences in the Earnings of Women and Men" (Pidgeon 1937), relied similarly on data about particular industries (manufacturing, sales, and clerical), most of it focused on particular states. Dickinson's analysis, like that of the Women's Bureau, showed that women were typically paid less, even within the same industry. The overall

influential in advocating against the elimination of protective legislation (workplace rules that differentially protected women workers) and thus against the Equal Rights Amendment (ERA). In the second half of the $20^{\text {th }}$ century, the politics of the Bureau shifted towards support for the ERA. Even before that shift, the Bureau was influential in fighting for the Equal Pay Act in the post-WWII era, as discussed below. 
gender wage gap figure in its modern form is not present, although his article does provide related statistics in a footnote: drawing on data from the newly-created Social Security system (which did not cover all occupations), other scholars had found that the average annual earnings "for white females was therefore about 50 per cent. of the average for white males, and the average for Negro females around 60 per cent of that for Negro males." (Dickinson 1943: 708) These statistics, reported in a footnote, were not given any special significance. Notably, Dickinson also wrote down his hopes that future studies of wage inequality would have access to data from within individual establishments to make direct comparisons possible: "Let me here express the hope that compilers of wage statistics will publish more data on intra-plant averages of earnings by sex, within same-named occupations. Such comparisons are of special importance for economic analysis, since the nature of the work is more likely to be homogeneous (under the same occupational name) within a plant than between plants." (Dickinson 1943: 714) As we will see, this hope remains largely unfulfilled to this day.

Following World War II, feminist activists from varying backgrounds united to apply pressure to achieve wage justice for women. This campaign involved calls for equal pay for comparable work, including introducing legislation at both the national and state level. At the federal level, the first Equal Pay Bill was submitted in 1945 and would have prohibited wage differentials for "work of a comparable character" (Cobble 2004). Writing in a special 1947 issue on "Women's Opportunities and Responsibilities" of The Annals of the American Academy of Political and Social Science, Dorothy Brady (an economist in the Department of Labor) made the case for the proposed bill. Like Dickinson, Brady (1947) pointed to the absence of data about specific workplaces which made it difficult to substantiate claims of within-job discrimination, drawing on a study of manufacturing plants in East Liverpool, Ohio to illustrate both the extent of within-job discrimination but also the larger problem of occupational segregation and the devaluation of women's work. ${ }^{4}$ The Women's Bureau held a prominent conference on equal pay in 1952 (Laughlin 2000). This conference gave birth to the National Committee for Equal Pay, with the American Association of University Women (AAUW) and the National Federation of Business and Professional Women's Clubs (BPW) taking leading roles. At the same time, labor unions were increasingly successful in negotiating equal pay provisions into union contracts, and unions continue to support legislative efforts (albeit sometimes motivated by the desire to prevent employers from undercutting men's labor rather than the push for wage justice). These efforts yielded success at the state level: just two states had equal pay laws on the book as of 1940, but 12 had them by 1952, and 22 by 1963 (Laughlin 2000: 40).

Throughout this period, the Women's Bureau continued to publish reports on gender differences in pay, but also continued to note problematic absences in data, especially outside of manufacturing industries. For example, in the early 1950s, Women's Bureau statistician Mildred Barber circulated an extensive memo within the Bureau of Labor Statistics calling the BLS out for failing to provide data on women workers by industry, while the Women's Bureau lacked the staff

\footnotetext{
${ }^{4}$ Interestingly, Brady (1947: 59-60) does cite figures on the aggregate gap in median full-time earnings (the modern gender wage gap) at the end of her article - but largely to make the point that many men and women did not make a sufficient income to support a family. Nonetheless, this remains one of the earliest examples of this statistic's use in the equal pay debate.
} 
and resources to produce its own analyses (Laughlin 2000: 54). Women's Bureau publications begin to include more data on earnings in the mid-1950s including figures like the contemporary gender wage gap; for example, "Spotlight on women in the United States, 1956-1957" reports a comparison of the annual earnings of men and women who work full-time, with men averaging $\$ 4,246$ and women $\$ 2,734$ (Beyer 1957: 34). This comparison is presented alongside many others, given no special significance, and follows extensive discussions of women being less likely to work full-time, more likely to work in lower-paid occupations, and also likely to be paid less even working in the same jobs (which was still legal in most states). These figures were also given little attention in media debates around gender inequality which tended to focus on statistics about women's increased participation in the paid labor force rather than differences in earnings, even when the topic was equal pay legislation. ${ }^{5}$

By the early 1960s, then, data on gender wage inequality were beginning to circulate more widely, linked in part to pressure from the feminist movement to pass a national-level equal pay bill. These efforts would pay off, in part, in 1963 with the passage of the Equal Pay Act (EPA). The next section traces the passage of the EPA, and the 1964 Civil Rights Act, and the compromises in the language of those acts that would help to set up the next five decades of confusion surrounding the gender wage gap.

\section{Equal but Incomparable}

The first bill proposing to ban sex discrimination in wages was introduced in 1945. Legislators would continue introducing versions for the next 18 years until the Equal Pay Act was finally passed and signed in 1963. After an initial flurry of activity in the immediate post-war period, the bill got little traction for more than a decade. Congress held one hearing on the Equal Pay Act proposal in 1950, and then no further hearings until 1962. In this section, I briefly recount the process by which the Equal Pay Act passed, with special attention to how labor union leaders, feminist activists, and business groups mobilized statistics and data to make claims about the necessity for an equal pay law (or the lack thereof), and about the sources of inequality in earnings. This section also shows how the debate centered around the interpretation of the words "comparable" and "equal", with the final language of the bill only banning pay disparities between "equal" work, in line with the requests of employers and over the objection of many union groups and feminist activists who worried that such narrow language would weaken the law to the point of complete inefficacy given the extent of gendered job segregation. Readers interested in more detailed accounts should consult the excellent history by Cobble (2004).

Academics were notably absent from these events. In the hearings held in 1950, and the four hearings held in 1962-1963 (one in the House and one in the Senate in each year), not a single academic testified as an expert on gender earnings inequality. The main experts, and almost the only sources of economy-wide statistics, come from the Women's Bureau of the Department of

\footnotetext{
${ }^{5}$ New York Times. 1955. "Congress Urged to Equalize Pay For Equal Work by Both Sexes." New York Times, 26. And New York Times. 1962. "Bill for Equal Pay Regardless of Sex Approved by House".
} 
Labor, especially Assistant Secretary of Labor Esther Peterson who testified at each of the hearings in 1962-1963 and provided extensive information and analysis. The only academic social scientists to testify were economists who presented themselves as representatives of the American Association of University Women testifying in their organizational capacity rather than as experts on labor markets or discrimination. And virtually no social scientific research is cited by any of the labor leaders, business groups, or feminists who testified. This absence contrasts markedly with the number and diversity of academic perspectives on gender wage inequality that emerge in the 1970s, and which dominate the debates over comparable worth discussed below. But up through the early 1960s, before the growth of human capital theory (Blaug 1976) and the take-up of surveybased micro data (Stafford 1986), there is very little academic research on the topic, and what there is seems to be irrelevant to the political conversation.

Although the absence of academics was constant across the hearings, there was a notable change in the amount and kind of statistical information presented in the 1962-1963 hearings as compared to 1950. Assistant Secretary Peterson was one of the first to testify at each of the four hearings, and included an extensive accompanying document titled "Economic Indicators Relating to Equal Pay" that summarized research by the Women's Bureau. This research included multiple kinds of evidence about the extent of disparities, as well as details about the 22 state-level equal pay acts already in effect. The main forms of evidence included information on occupation-level disparities (much like the kinds of statistics discussed above), a catalog of examples of employers specifically advertising different pay starting pay rates for men and women being hired for the same positions, and, interestingly, statistics on what we now identify as "the gender wage gap": the difference (and/or ratio) between the median annual earnings of full-time employed men and women. Figure 3, from the 1962 Senate hearings (Senate Hearing 1962: 47), showcases both the overall gap as well as the gap within particular occupations. 
Chabt III

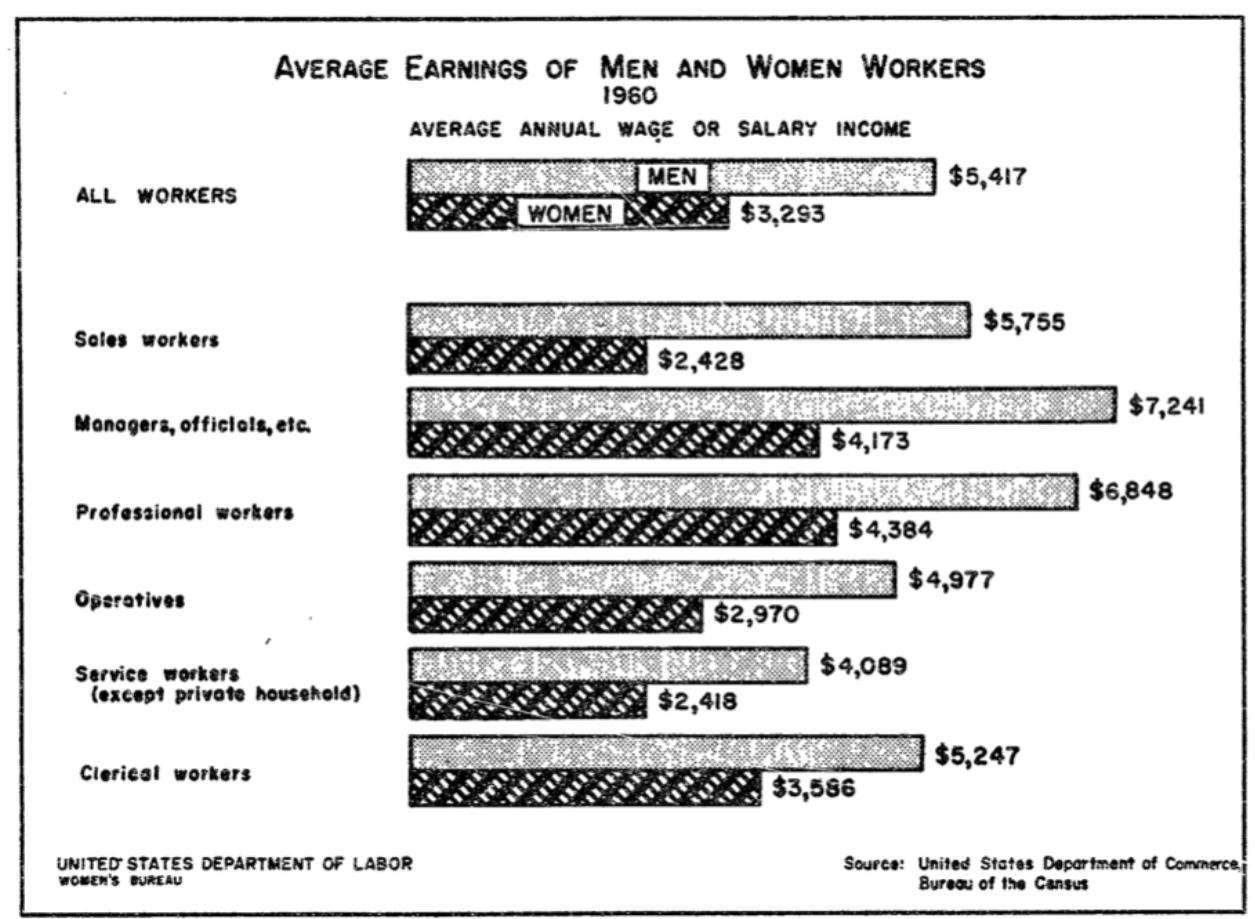

Figure 3: From the 1962 Senate Hearings on Equal Pay, p. 62.

The accompanying testimony and documents made clear that the overall gap could not be attributed solely to the kind of discrimination that would be banned by the equal pay act (whether in its weaker "equal work" or stronger "comparable work" language): "These differences are related primarily to the different types of jobs men and women hold, but they reflect also a variety of other factors, including amount of education and work experience, industry of employment, size of company, location of plant or office, and even wage differentials based on sex." (Senate Hearing 1962: 45). Despite this seemingly large caveat about its direct relevance of to the narrower question of specific employers paying men and women different wages for similar work, the aggregate pay gap statistics seemed to strike a chord. They are cited by many who testify in favor of the bill, including legislators like Representative Jessica McCullough (a co-sponsor of one of the equal pay bills, and member of the influential President's Commission on the Status of Women), union leaders like William Schnitzler (Secretary-Treasurer of the AFL-CIO), and feminist activists like Katherine Peden of the BPW. Some of these supporters were careful to note that the aggregate wage gap included many factors, while others made stronger connections to the kind of discrimination they hoped to make unlawful. For example, Senator Maurine Neuberger from Oregon testified: "The evidence of discrimination is overwhelming, and is rarely denied. When women work full time their levels of earnings compare unfavorably with those of men. In 1960 they amounted to about 60 percent of the men's total." (Senate Hearing 1963: 14)

In a pattern that comes to define the debate over the gender wage gap, business groups were quick to point out the inadequacy of these aggregate statistics for measuring same (or similar)-job, different-pay discrimination. While business groups like the National Association of 
Manufacturers (NAM) claimed to support the principle of equal pay for equal work, they largely opposed the specific bills proposed by Congress, and repeatedly argued that such federal intervention was unnecessary. As part of these arguments, they contested the extent of pay discrimination, arguing that collective bargaining agreements and modern techniques for pay setting like job evaluation had largely eliminated pay disparities. They specifically argued that "Comparisons of the average weekly and hourly earnings of men and women are especially misleading." (House Hearings 1962: 165) These discrepancies, they argued, reflect differences in seniority, experience, hours worked (even among full-time workers, men typically work more hours than women, and were and are more likely to work overtime), and productivity for jobs that piece rates, among other factors. The Chamber of Commerce echoed NAM, arguing that "It is practically impossible to determine statistically whether or not men and women now receive 'unequal' pay when doing 'equal' work." (Senate Hearings 1962: 101) This conclusion is far stronger than the one reached by the Women's Bureau, although it rests on a similar understanding of the complexity of interpreting aggregate pay differentials and it showcases how the central statistics of the "gender wage gap" was from the very beginning poorly matched to policy debates about pay discrimination.

Opponents of the Equal Pay Act had one further, related argument: employing women was more expensive than employing men. Employers and business groups argued that women employees were limited by existing laws in ways that made them less flexible (for example, some states had laws banning women but not men from night shift work, or requiring paid breaks for women workers but not men). Additionally, employers argued that women faced higher rates of absenteeism and higher rates of turnover, often connected to family obligations (especially children). In the 1963 Senate Hearings, the last hearings before the final passage of the bill, Esther Peterson argued that employers were incorrectly lumping together all women in their analysis. Rather, she argued: "A careful analysis of various impartially collected statistics on absenteeism and labor turnover indicates that the skill level of the job, the age of the worker, the worker's length of service with the employer, and the worker's record of job stability - all give a much better clue to an understanding of differences among workers than does the mere fact that the worker is a man or woman." (Senate Hearing 1963: 21) Here, Peterson argued that employers were not controlling for enough in their analysis and were thus attributing differences to gender that could be explained by other variables that men and women happened to differ on. ${ }^{6}$

The final bill was a compromise. Employers could not prevent the passage of the law, but the final bill did include one of their main requests: replacing the language of "comparable work" with the language of "equal work". In 1962, the bill reached the floor of the house where it was debated and amended. Representative Katharine St. George, a Republican from New York, offered the amendment to replace "comparable" with equal", and gave a stirring speech, invoking Susan B. Anthony, to argue that "equality is what we want: nothing less and nothing more." (Congressional Record 1962: 14768) Representative Herbert Zelenko, a Democrat from New York who was overseeing the equal pay bills and chaired the hearings on the bills in 1962, argued that this

${ }^{6}$ This sort of argument also characterizes the debate over the use of sex as a variable in pricing life and auto insurance. See Krippner \& Hirschman 2021. 
language would dramatically weaken the bill by making it trivial for employers to evade by introducing small differences between men and women's jobs: "If you put in the word "equal", we will have no equal pay bill." (Congressional Record 1962: 14771) St. George's amendment carried narrowly, and the language was changed to "equal." Although both houses subsequently passed bills in 1962, the two versions could not be reconciled for procedural reasons, and the whole process was restarted in 1963 with the new congress. Zelenko had lost his seat, and the new bills that were introduced adopted the "equal work" language that had passed in the previous year over the continued objections of some longtime supporters, like Esther Peterson, and Representative Edith Green, a Democrat from Oregon who had been pushing for an equal pay bill since 1955. The Equal Pay Act was signed into law on June 10, 1963.

In their coverage of the law's passage, the New York Times included the same statistics on the aggregate gender wage gap that was referenced so frequently in the congressional hearings. The paper noted the limitations of the law and specifically how those limitations would prevent it from closing the wage gap: "The 1960 census indicated that the average women worker earned $\$ 3,293$, as against $\$ 5,417$ annual average for men. Most of that differential will vanish only when the principle of equality extends from wage rates to job advancement." " In 1964, Congress passed the Civil Rights Act, which included Title VII that did just that, banning sex discrimination in all aspects of employment, including hiring and promotion. Title VII did not, however, expand on the Equal Pay Act's narrow definition of pay discrimination, a point I will return to below. Nonetheless, the aggregate disparities in the gender wage gap that were cited so frequently in the hearings over the Equal Pay act would persist and remain remarkably stable for the next 15 years. And they would become a routine statistical production, widely reported and cited. The recognized persistence of this pay gap in spite of formal legal prohibitions on employment and wage discrimination would help fuel a massive increase in research around wage disparities, as well as a new generation of feminist activism frustrated with the tepid rate of progress on achieving economic equality.

\section{Studying the Gender Wage Gap}

Before the 1960s, the gender wage gap was not a stylized fact. After the debates surrounding the passage of the Equal Pay Act in 1963, it rapidly became one. By the mid-1970s, the gender wage gap had become a standard indicator used to track progress (or the lack thereof) in achieving economic gender inequality, as well as for comparing the relative levels of gender inequality across nations. This rise in public attention also coincided with a massive increase in the amount of research on gender wage inequality. This research fit neatly into the emerging research program in labor economics that brought together human capital theory, survey data, and statistical regression methods. This combination made it possible for scholars to try to put precise numbers on the importance of education, experience, industry, occupation, age, hours worked, and more, as explanatory factors that led to women making about $40 \%$ less than men throughout the 1960 s1970s.

${ }^{7}$ New York Times. 1963. “Equal Pay for Women.” 13. 
Starting in the 1960s, the Women's Bureau began to include statistics on the gender wage gap in its publications. These statistics drew on the Census Bureau's regular reports on income ("Current Population Reports: Consumer Income", known as Series P-60), which compiled tables from the Current Population Survey and offered a breakdown of income by sex and full-time work. In doing so, the Women's Bureau extended the statistics presented in the Equal Pay Act debates, making it possible to track movement (or, in this case, stagnation). For example, in 1965, the Bureau reported that full-time employed women's median wages were still about $60 \%$ of men's (Women's Bureau 1965). These reports drew some media attention like a 1964 New York Times story “Women's Pay Gap is Still Widening, U.S. Official Says", which quoted Women's Bureau Director Mary Dublin Keyserling at length. ${ }^{8}$ Such stories increased in the early 1970s as the aggregate data continued to show flat or increasing gaps. A 1972 article, "Pay Gap Widens Between Sexes" cited the new head of the Women's Bureau, Elizabeth Duncan Koontz who reported the continued decline of women's median wages: "a woman working full time in 1970 made only 57 per cent of a man's income, down from 64 per cent in 1955." At this point, the "pay gap" still shows up in quotes inside the article - the stylized fact is beginning to take hold, but is still seen as a novel construction. By the end of the 1970s, the quotes would fall away and the gap would become more central in the framing of economic inequality. For example, in 1976 the Women's Bureau published a report titled "The Earnings Gap between Men and Women" and the pay gap statistic moved from being just one of many numbers to reported to being the first sentence of the report, around which was framed 12 pages of analysis. A sequel with the same title in 1979 expanded to 22 pages. These publications were in turn written up in the media who highlighted both the aggregate trend, and also the explanations offered by the Women's Bureau: the combination of women's continued concentration in lower-paid occupations, the large increase in women's labor force participation which meant that women were disproportionately early in their careers than men, and also the persistence of discrimination. ${ }^{10}$

At the same time, the gender gap also began to be used by international organizations seeking to compare the status of women across countries. The Organisation for Economic Co-operation and Development (OECD) began publishing reports surveying the situation of women workers across countries as early as 1965 (Klein 1965). ${ }^{11}$ Notably this initial publication included no comparative discussion of wages or wage gaps. By 1975, the updated report "The role of women in the economy" included some data on earnings gaps although it noted the paucity of statistics for most countries, rendering "full international comparisons" impossible (Darling 1975: 58). The OECD now maintains a standardized annual data series on the gender wage gap covering the 37 OECD countries and going back as far as 1970 where data are available (OECD 2021).

\footnotetext{
${ }^{8}$ Anon. 1964. "Women's Pay Gap Is Still Widening, U.S. Official Says.” New York Times, 35. ${ }^{9}$ Lyons, Richard. 1972. "Pay Gap Widens Between Sexes: Labor Department Official Describes 'Grim Picture."” New York Times, 34.

${ }^{10}$ Shanahan, Eileen. 1976. "Gap in Earnings Between the Sexes.” New York Times, 18; Wall Street Journal. 1976. "Pay Gap Has Widened Between Men, Women.” April 27, 19.

${ }^{11}$ I thank Ruud Bruijns at the OECD for helping me find and access the OECD's earliest reports on women and work.
} 
This increased national and international attention to earnings gaps was matched by a rapid increase in academic research. While some academics, like Dickinson (1943) discussed above, had treated the topic of wage differences between men and women, there were relatively few accounts and those that existed drew mostly on idiosyncratic and smaller-scale data. Starting in the 1960s, and increasing rapidly in the early 1970s, academics began to research the determinants of the economy-wide gender wage gap with a focus on the extent to which that gap could be attributed to discrimination. In 1960, Henry Sanborn completed a dissertation at the University of Chicago titled "Income Differences Between Men and Women in the United States," results from which were published a few years later (Sanborn 1964). Drawing on 1950 Census data, Sanborn attempted to statistically adjudicate how much of the pay gap was attributable to occupation, hours worked, education, age, race, and geography (rural vs. urban). Sanborn concluded his analysis by arguing that pay disparities are mostly explicable by productivity-related factors, and thus "if discrimination is an important cause of male-female income differences, it is not discrimination by employers but by consumers and fellow employees that is effective" (Sanborn 1964:548-549). As far as I can tell, this is the first example of what became an entire research tradition containing thousands of papers devoted to decomposing the gender pay gap and attempting to determine what, if anything, was attributable to discrimination (and what sort of discrimination).

In the early 1970s, many more papers adopted versions of this approach, including an extremely influential paper by Ronald Oaxaca (1973) that explicitly decomposed the gender pay gap using a technique now known as the Oaxaca-Blinder-Kitagawa decomposition. Controversially, Oaxaca argued that the residual earnings disparity that existed after controlling for observable variables should be treated as an estimate of discrimination. In turn, his analysis suggested that while "unequal pay for equal work does not account for very much of the malefemale wage differential..." it was the case that "a substantial proportion of the male-female wage differential is attributable to the effects of discrimination." (Oaxaca 1973: 708) In this account, discrimination acted primarily by concentrating women into lower-paying occupations, thus ensuring that women earned less than men with similar personal characteristics (such as education). By 1973, Isabel Sawhill (1973) could summarize an emerging literature on explanations of the gender wage gap, citing Sanborn, Oaxaca, and four other similar works that tried to decompose the overall gap, along with her own analysis. ${ }^{12}$ Like Oaxaca, Sawhill argued against controlling for occupation because the main routes for discrimination involved placing women into lower-playing occupation rather than the sort of discrimination banned by the Equal Pay Act:

It would, of course, be quite easy to substantially reduce the remaining differential by resorting to an occupational adjustment, and the finer the occupational classification used, the smaller the differential would be. However, this procedure

\footnotetext{
${ }^{12}$ A handful of sociologists were involved in this conversation at the time, including Suter \& Miller (1973), who are included in Sawhill's review. Overall, the conversation was dominated by economists, and even the sociologists tended to write in dialog with economic theories (see Marini 1989 for an exemplary review of the literature by a sociologist framed around the same human capital vs. discrimination debate as in economics).
} 
would not explain why women who are well qualified with respect to education and experience continue to be relegated to relatively low-paid occupations. (Sawhill 1973: 391)

Sawhill ended her analysis by noting the relative futility of equal pay laws and the promise of strongly-enforced equal opportunity legislation to breakdown occupational barriers. But she also warned that "wholesale reform of sex roles and of the existing institutions of marriage and childrearing is the necessary prerequisite to equal opportunities in the labor market." (Sawhill 1973: 394) Employer discrimination, for Sawhill, resulted from a partially accurate, partially false, belief that women would prioritize family obligations and their husbands' careers over their own.

The debate over the interpretation of these earnings regressions and decompositions was heavily influenced by the rise of human capital theory. Since the late $19^{\text {th }}$ century, mainstream economists had argued that wages were a function of productivity. The "marginal productivity theory of income distribution" argued that employers in a competitive economy would pay workers exactly as much as their labor was worth (Pullen 2009). In the 1950s and early 1960s, economists expanded this theory by arguing that workers would rationally invest in their own productivity, for example by seeking out education or training, increasing their "human capital" (Teixeira 2007, Teixeira 2014). This theory offered explanations for numerous stylized facts, such as the gap in earnings between more and less educated workers, and also promised to unify distinct phenomena from education to health to migration into a single framework, imagining individuals as forwardthinking investors in their own future productivity (Blaug 1976).

In the early 1970s, human capital theorists turned to the debate over discrimination and the gender pay gap. Perhaps most influentially, Jacob Mincer (one of the founders of human capital theory) and Solomon Polachek (1974) analyzed sex differential in earnings using human capital theory's model of the family as a single economic unit that shares consumption and production decisions, including decisions about investing in human capital. In this model women - especially wives and mothers - specialize in non-market labor, including planning for career interpretations related to family obligations, and thus invest less in their careers and career-relevant training. In turn, these career interpretations lead to their market-relevant skills decaying, and thus reducing their productivity when they do reenter the labor force (or convince them not to, if the wage they could obtain is too low). Men, in contrast, plan for uninterrupted working careers, and make investments accordingly. As a result, not only do women of the same age have fewer years of work experience and their men counterparts, but also years of work experience produce lower rates of return for women. Mincer and Polachek (1974: S104) were reticent to rule discrimination in or out, especially what they termed "indirect" discrimination where expectations of labor market discrimination might rationally lead women to invest less in job-relevant skills (e.g. why bother going back to school for an MBA if no corporation would ever promote you into the executive suite?). And somewhat tellingly, they noted that if the definition of discrimination is broadened to include the division of labor within the family itself (as many feminists might argue), "all of the gap is by definition a symptom of discrimination." (Mincer and Polachek 1974: S104) Rather than adopting this expansive definition, human capital theorists instead foregrounded women's 
occupational choices - shaped by their family priorities - as the drivers of occupational segregation (Chassonnery-Zaïgouche et al 2019: 28).

Mincer and Polachek's findings, and human capital theory explanations that were taken as foregrounding rational decision-making around the gendered division of labor within families as the main source of gender wage inequality, were and remain controversial. Alongside the human capital model, Blau and Jusenius (1976) identified at least four other economic explanations, including overcrowding (that discrimination forces women into a small set of occupations, where supply then outstrips demand as in Bergmann 1974) and internal labor market theory (which focuses on how entry-level jobs shape the opportunities for promotion within firms, and how men's entry-level jobs are much more likely to have clear opportunities to advance). And later researchers, including feminist sociologists, argued that the empirical predictions of human capital theory were not borne out. For example, Paula England (1982) argued that human capital theory's attempts to explain occupational sex segregation were inconsistent with evidence showing that women who left the labor force faced similar penalties whether they were employed in primarily female or primarily male occupations, undermining the argument that women were rationally opting to work in careers that favored interrupted careers.

Stepping back from the ins and outs of the academic debates of the 1970s, what's striking is simply the amount of research that came into existence and how much the gender wage gap became a focal point for the conversation. It became something to be explained. This intense academic attention meant that when public attention turned again to debating the causes of gender wage inequalities, academics were ready to play a central role in a way they had not been in the 1950s1960s. At the same time, academic research in labor economics (and in sociology) was relatively unable to address the precise dynamic made illegal by the Equal Pay Act: different pay for the same work by the same employer. The studies in this period - and almost all of the research done through to the present - rely on either data from the Census or from large-scale household surveys. None of these datasets matched employers and employees. ${ }^{13}$ Academics largely agreed that this now-illegal form of discrimination was a relatively small part of the remaining gender wage gap, and focused their attention elsewhere: on issues of the division of labor within families, occupational segregation, the role of on-the-job training, and career tracking through internal labor markets.

At the same time, the attention to the stagnation in the top-level gender wage gap helped fuel a new generation of feminist activists who blamed the lack of progress on the failures of the government to adequately enforce civil rights law. In turn, these activists would revive debates about equal and comparable work, eventually arguing that women's work was devalued because women did it, and that this form of discrimination was amenable to legal remedy under the Civil Rights Act, if not the Equal Pay Act. These issues would take center stage as the feminist movement initiated a new campaign in the late 1970s to address the stubbornly persistent gender wage gap.

\footnotetext{
${ }^{13}$ For a rare exception from a government statistician, see Buckley 1971 which reported withinestablishment differentials for 10 narrow occupations.
} 


\section{Fighting the Stalled Wage Gap}

When the Equal Pay Act passed in 1963, the reported gender wage gap was around 60 cents on the dollar. Over the next two decades, that number moved very little. As early as the mid-1960s, feminist activists noted the apparent stagnation and mobilized around it. By the late 1970s, the stalled pay gap would become a motivating frame for a new movement around pay equity and comparable worth. This movement won several major legal and economic victories, but fizzled out after a string of hostile regulatory and court decisions undermined its core strategy in the mid1980s. These legal and regulatory debates, unlike those of the 1960s, would be deeply informed by the new economics of gender inequality that emerged in the 1970s.

Title VII of the Civil Rights Act of 1964 banned sex discrimination in employment. The political compromises that led to the inclusion of sex discrimination were complicated - a strange alliance of feminist legislators and Southern Democrats trying to sink the entire bill - but in the end, the sex discrimination provisions were passed into law. The Equal Employment Opportunity Commission (EEOC) was then set up to enforce the act. In its first years of operation, the EEOC faced a flood of complaints including many alleging sex discrimination in pay, benefits, hiring, promotions, and more (Kessler Harris 2001). While these complaints clearly fell under the heading of the EEOC's legal mandate, the EEOC instead prioritized racial discrimination claims. This prioritization was in part justified by the argument that sex discrimination was only included in Title VII as a kind of joke:

Aileen C. Hernandez, the only woman and one of two persons of color among the original five commissioners, recalled later that she had "found no humor in the frequently repeated statement that sex' had found its way into Title VII as a 'fluke'that it was a 'joke' — that it did not need to be enforced — that the 'real' discrimination in society was on the basis of race and ethnic origin and that's where the emphasis of the commission should be directed. (Kessler Harris 2001: 248)

This attitude pervaded the EEOC itself as well as many public discussions of sex discrimination which often ridiculed the very idea that sex discrimination in employment ought to be unlawful. For example, a New York Times write-up of an EEOC conference "devoted much of its space to covering a short discussion of what might happen if a male applied for a job as "bunny" in one of the Playboy clubs. The Times promptly ridiculed efforts to eliminate sex discrimination as the "bunny problem," assuring readers in an editorial that "it would have been better if Congress had just abolished sex itself.", (Kessler Harris 2001: 249)

In 1966, in response to these dismissals, and more generally to the perception that the government was not doing enough to end sex discrimination, feminist leaders associated with the President's Commission on the Status of Women (most notably Betty Friedan and Pauli Murray) and the EEOC (including Hernandez, as well as Sonia Pressman Fuentes and Richard Graham) founded the National Organization for Women (NOW) (Kessler Harris 2001, Turk 2016). NOW's founding statement of purpose, adopted in October 1966, explicitly drew attention to the apparent increase in the wage gap: 
Despite all the talk about the status of American women in recent years, the actual position of women in the United States has declined, and is declining, to an alarming degree throughout the 1950's and 60's. Although 46.4\% of all American women between the ages of 18 and 65 now work outside the home, the overwhelming majority - 75\% - are in routine clerical, sales, or factory jobs, or they are household workers, cleaning women, hospital attendants. About two-thirds of Negro women workers are in the lowest paid service occupations. Working women are becoming increasingly — not less - concentrated on the bottom of the job ladder. As a consequence full-time women workers today earn on the average only $60 \%$ of what men earn, and that wage gap has been increasing over the past twenty-five years in every major industry group. ${ }^{14}$

These statistics - largely the same as those cited by Esther Peterson in the Equal Pay Act hearings - offered a focal point for diagnosing gender economic inequality. For the next two decades, the feminist movement, including NOW, would emphasize the connections between occupational segregation, the devaluation of women's work, discrimination in promotions, and the overall gender wage gap. For example, in the late 1960s, NOW lobbied and protested the EEOC, pressuring them to take sex discrimination more seriously. These efforts eventually yielded concrete policy changes at the EEOC that clarified what constituted sex discrimination by incorporating clear standards developed for identifying racial discrimination (Kessler Harris 2001: 250).

Although the EEOC began to adopt clearer and more uniform standards, debates over racial and sex discrimination moved in somewhat different directions. While the absence of Black employees was taken as evidence for discrimination and as cause for government intervention (such as mandated affirmative action hiring), the same did not hold for the absence of women. Employers argued, and many agreed, that occupational sex segregation reflected not discrimination but rather "women's own preferences for raising families, their willingness to place their own careers second to their husbands', and their ambivalent attitudes toward wage work" (Kessler Harris 2001: 277). This choice vs. discrimination framing launched what Kessler Harris (2001: 277) rightly calls "an endless debate", one that persists into the present (as the next section will show).

By the end of the 1970s, the feminist movement had achieved many concrete policy goals. Sex discrimination was banned, the EEOC had achieved new enforcement mechanisms, and corporations had begun to at least nominally increase the hiring of women into managerial and professional roles (Kelly and Dobbin 1998). And yet the overall wage gap had not budged. In the debates over the Equal Pay Act, Peterson had testified that full-time employed women made just $59 \%$ of what men made in 1962. In 1979, the number was unchanged. News stories around gender inequality noted this stagnation, dating it back as far as the 1930s, and feminists circulated the statistic widely, stamping it into buttons and printing it on leaflets, putting a bit of style into the

${ }^{14}$ Available at https://now.org/about/history/statement-of-purpose/, accessed February 25, 2021. 
stylized fact (McCann 1994: 23, Cobble et al 2014: 141). ${ }^{15}$ The flat gender wage gap also had a clear underlying explanation: the persistence of occupational sex segregation coupled with the devaluation of women's work. Frances Hutner, an economist who later authored a book on comparable worth (Hutner 1986), put the issue starkly to the NYT: "The main problem... is that women are trapped in female occupational ghettos." 16

Although some economists offered competing explanations - foregrounding women's familyrelated obligations and the burdens of motherhood, for example, as we saw in the previous section - this occupational segregation-focused story captured the attention of the feminist movement. This framing helped to galvanize a new coalition of labor leaders and feminist activists who mobilized around revitalizing and expanding an old strategy: comparable worth. In 1979, the National Committee on Pay Equity (NCPE) was launched as a collaboration between a broad group eventually containing more than 100 organizations including labor unions and NOW, among many others (Turk 2016, Hower 2020). The movement to revalue women's jobs had two major prongs: a legal strategy centered around expanding the interpretation of Title VII (McCann 1994, Nelson and Bridges 1999), and a workplace activism strategy rooted especially public-sector unions like AFSCME (Hower 2020).

Both approaches identified employers' own job evaluation practices as strategically useful for making the claim that women's jobs were systematically undervalued. Formal job evaluations involve scoring jobs based on various features (such as skill, effort, responsibility, and working conditions) and then assigning a pay rate to each job based on its score (National Research Council 1981; see especially Adler 2020 for a more comprehensive overview and history). Formal job evaluations had existed for decades, and employers even cited the extent of job evaluations as one reason why the Equal Pay Act was unnecessary - because job evaluations assigned a "rate for the job" rather than for the particular employee who occupied it, sex discrimination was (in their understanding) impossible. Comparable worth advocates argued that while job evaluation practices might have eliminated the sort of same-job, different-pay disparities that the Equal Pay Act targeted, they also showcased the pervasive underpayment of jobs occupied primarily by women. For example, a study made at the request of employees from the State of Washington in 1974 showed that "for jobs rated equally by the job evaluation system, those held mainly by men were paid 20 percent more on the average than those held mainly by women." (National Research Council 1981: 3) In the case of Washington state, this study became the focal point for a decadeslong campaign for pay equity, and government employees across the country followed suit, from municipal workers in San Jose, CA to state employees in Connecticut and Florida (Hower 2020). In 1981, workers in San Jose even went on strike to protest the unwillingness of city hall to remedy the inequities revealed by a city-level pay equity study (Hower 2020: 674).

The local and state-level labor actions were matched by a national-level effort that centered on the EEOC and the interpretation of Title VII. In 1980, EEOC Chair Eleanor Holmes Norton held extensive hearings on the relationship between job segregation and wage discrimination. While

\footnotetext{
${ }^{15}$ Rosenbaum, David. 1980. "Working Women Still Seek Man-Sized Wages: Pockets of Success, Not a Trend.” New York Times, E3.

${ }^{16}$ Bennetts, Leslie. 1979. "The Equal Pay Issue: Focusing on 'Comparable Worth':

'Occupational Segregation’ A Suit Is Brought.” New York Times, A20.
} 
not entirely focused on comparable worth, the bulk of the testimony centered around the legal and social scientific questions raised by the issue. In her opening statements, Norton highlighted the growing gender wage gap and the possibility that it could be explained by the devaluation of jobs held primarily by women:

The worsening of the gap between men and women, despite some progress in opening access to formerly closed jobs and during the very years of the operation of Title VII and the Equal Pay Act creates some urgency in looking beyond the known traditional causes, but until recently both the government and private parties have generally treated wage discrimination and job segregation as separate and largely unrelated matters. (EEOC 1980: 7)

In stark contrast to the 1962-1963 debates over the Equal Pay Act, the 1980 EEOC hearing would include a wealth of social scientific expertise from different perspectives. Social scientists testified about studies they had conducted using various kinds of data to address the sources of the wage gap and the extent to which discrimination of one kind or another could account for its surprising persistence. Alexis Herman, the director of the Women's Bureau's, testified to the stability of the gender wage gap and offered two main explanations: that women remained concentrated in lower-paying, traditionally female occupations, and that a recent large increase in women's participation in the paid labor force led to "an even larger concentration of women who are at the bottom of the economic ladder" (EEOC 1980:346). Notably this explanation implied that the wage gap might soon improve absent any notably policy changes as this cohort of women gained more work experience. ${ }^{17}$ Mary Corcoran, a political science professor from the University of Michigan, testified about her research that drew on the Panel Study of Income Dynamics (PSID) to show how white men had much better access to job training and that this training explained some of the persistent wage gap. Barbara Bergmann, an economics professor at the University of Maryland, reinforced the centrality of sex segregation to explaining the wage gap, and also argued that women were more often required to pay for their own training - a finding consistent with Corcoran's research but, in her mind, incompatible with human capital theory. Bergmann put the point clearly:

"[Women] have already at their own expense provided themselves with nurse's training. They have already at their own expense given themselves master's degrees in social work, and these social scientists are alleging that these women, the problem, the reason women have lower pay is that these poor women don't feel like accumulating human capital, but that is trash." (EEOC 1980: 316)

\footnotetext{
${ }^{17}$ Goldin (1990) provides evidence for precisely this argument in her book-length treatment of the gender wage gap. This narrative offers an explanation for why the wage gap appeared to stagnate in the 1970s, when EEOC enforcement and affirmative action programs were at their height, and then appeared to improve rapidly in the $1980 \mathrm{~s}$, when these programs were in decline. In this argument, the gender wage gap was a lagging indicator of changes in gender equality in the labor market.
} 
In contrast, Andrea Beller, an economics professor from the University of Illinois, drew on CPS data to argue that much of the wage gap could be explained by human capital theory and that labor market discrimination seemed to be on the decline precisely due to the enforcement of the Civil Rights Act. An exchange between Beller and EEOC Commissioner Ethel Bent Walsh is revealing for how it showcased competing understandings of choice and discrimination. Beller agreed that discrimination could manifest in terms of lower pay to women's occupations, but argued that economists must first rule out non-discriminatory explanations rooted in women's preferences for flexibility or safety (for example), and that to the extent wage discrepancies were rooted in those preferences, it would be wrong for policymakers to intervene:

Professor Beller: "In order to determine by how much wages in women's occupations are discriminatorily depressed, we must first establish to what extent women's occupational distribution reflects choice and to what extent discrimination."

Commissioner Walsh: "I am trying to get on that theory what came first, the chicken or the egg, because when you talk in terms of reflecting choice, if that choice is very limited, does that not, in effect, extend to discrimination?"

Professor Beller: "what I am trying to say is that it is not true that the entire wage difference between women's jobs and other jobs is the result of discrimination... preferences have some role in which occupations people go into, and to the extent that that is operating and wage differences reflect those preferences, we would not want to intervene. There would be no justification for doing anything about that because it is what people want." (EEOC 1980: 300-301)

Here we see another example of the "endless debate" that Kessler Harris identified between explanations of gender disparities in terms of choices vs. discrimination. What changes are the details and who is authorized to speak. In contrast to earlier periods, social scientists were increasingly tasked with interpreting the quite technical details. In so doing, particular disciplinary understandings of concepts like discrimination and preferences came to the fore. For Beller, and for human capital theorists (and most orthodox economics more generally), if a difference was rooted in women and men's different preferences, then there was nothing to be done about it. Preferences were sacred. In contrast, feminist economists like Bergmann rejected both the empirical analysis provided by human capital theorists and their interpretations of gendered preferences as somehow outside of the political sphere.

The EEOC hearings included plenty of testimony from more traditional sources as well - labor unions and business associations foremost among them. Testimonies from the Business Roundtable and Chamber of Commerce are particularly revealing because both take time to specifically engage with the gender wage gap per se, and to argue that it should not be interpreted as a measure of discrimination. William Knapp, a lawyer testifying on behalf of the Chamber of 
Commerce, for example, cited the Women's Bureau (1979) publication showing the wage gap at 59 cents on the dollar, but then went on to say, "The statistic alone is meaningless and can be very misleading." (EEOC 1980: 716) Similarly, Virgil Day from the Business Roundtable argued that "This unrefined statistic, however, is not proven sex discrimination, let alone a pay difference prohibited by federal law." (EEOC 1980: 671) Instead, Day went on, the wage gap should be seen as a reflection of women moving into entry-level jobs (just as Herman had argued on behalf of the Women's Bureau), along with other non-discriminatory factors like differences in education and industrial sector (women tending to work in "low-margin, highly competitive" industries"). None of these sources was amenable to a comparable worth-style fix, as none involved individual employers differentially compensating women's jobs less than men's.

The growing centrality of social scientific expertise was not limited to the EEOC hearings. Increasingly, social scientists testified in employment discrimination cases (ChassonneryZaïgouche 2020). The EEOC also sought more conclusive expert guidance in the form of expert report from the National Research Council of the National Academy of Sciences (Turk 2016: 119). Published in 1981, Women, Work and Wages: Equal Pay for Jobs of Equal Value largely endorsed arguments in favor of comparable worth, and specifically in favor of using employers' own job evaluation practices to judge whether or not women's occupations were systematically underpaid.

The combined efforts of labor unions, NCPE, and the EEOC seemed initially to bear fruit. In the early 1980s, AFSCME won various disputes that led to significant increases in the pay for some women (Hower 2020). And the Gunther Supreme Court decision in 1981 seemed to open the door to a legal theory that held that comparable worth claims could be brought under the Civil Rights Act (Nelson and Bridges 1999, Turk 2016). But these initial victories were fleeting. By 1985, the EEOC, now under the leadership of Clarence Thomas, soundly rejected comparable worth (Turk 2016: 121-122). And, as Nelson and Bridges (1999: 37-38) document, Federal Courts rejected comparable worth-based arguments so consistently that by the late 1980s plaintiffs simply stopped making them. Interestingly, the comparable worth movement did have one lasting implication: employers abandoning job evaluation systems en masse (Adler 2020). The threat of litigation in the early 1980s turned job evaluation's standardized pay-setting process into a liability that seemingly exposed inequalities between men and women's occupations. In court, employers were able to successfully argue that their practices were, in fact, dictated by market pressures, and these arguments were basically always upheld by the courts as sufficient justification no matter how flimsy the evidence provided (Nelson and Bridges 1999). Nonetheless, human resources professionals began to advise employers to make their practices match their rhetoric, and employers rapidly switched away from formal job evaluation systems in favor of market surveys (determining the market rate for specific jobs) and individual negotiations (often based on a candidate's salary history) that still dominate pay setting practices today (Adler 2020).

By the end of the 1980s, then, the gender wage gap had become institutionalized as one of the key indicators of gender inequality, various groups of experts (largely economists) competed to provide explanations for the gap, and the comparable worth movement had largely faded. While the NCPE continues on, and organizations like the AAUW continue to promote "Equal Pay Day" and other efforts to draw attention to the gender wage gap, no similar effort has emerged to replace the comparable worth movement in the fight against gender wage inequality. As a result, as I show 
in the next section, the conversation around the gender wage gap has turned away from explanations rooted in occupational segregation (despite its relative persistence) and towards explanations rooted in family life and women's choices. At the same time, misunderstandings of the gender wage gap rooted in its historical connection to the narrow legal definition of discrimination inscribed in the Equal Pay Act continues to characterize the debate.

\section{Opting Out, Leaning In, and Persistent Misunderstandings}

To understand the trajectory of conversations about economic gender inequality before and after the comparable worth movement, the following section draws on a hand-coded dataset of newspaper articles about the gender wage gap. The sample includes all articles from The New York Times, Washington Post, and Wall Street Journal from 1970-2014 that include either of the terms "wage gap" or "pay gap" and at least one of the term "women", "female", or "sex." This search yielded 912 articles. These articles were hand-coded for their discussions of issues related to gender inequality and their use of quantitative measures of gender inequality. A total of 520 articles were deemed relevant (that is, were actually about the gender wage gap, and focused on the United States). The full codebook is available upon request.

These data show how the end of the comparable worth movement, and other forces like the decline of labor unions and the rise of an anti-feminist backlash (Faludi 2006), led to a change in the conversation around gender wage inequality. After the 1980s, the gender wage gap persisted as a key hinge connecting policy debates, academic research, and public understandings but the narratives around the gender wage gap shifted absent pressure from the feminist labor movement forcing attention to occupational segregation and the devaluation of women's work. Instead, we see an increasing emphasis on women's choices such as the narrative of an "opt-out revolution" made prominent by a 2003 New York Times article. As Williams et al (2006) show, media narratives about women leaving the workplace emphasize women's choices without addressing the structural constraints (such as the absence of maternity leave or affordable childcare) under which women are forced to choose. Similarly, we see the rise of both academic research on motherhood pay gaps and media narratives that foreground that explanation, reaching a pinnacle with articles like a 2018 Vox.com piece titled "A stunning chart shows the true cause of the gender wage gap"18 that a chart with wage trajectories of men and women after they have kids (using data from Denmark, but purporting to explain similar trends in the United States).

At the same time, occupational segregation persists and social scientists agree that it remains one of the most important explanations for the persistent gender wage gaps. For example, Figure 4, reproduced from Hegewisch and Hartmann (2014), makes this link explicit, graphing trends in the two aggregate statistics (see England et al 2020 for a more recent discussion of the same patterns). Notably, occupational segregation barely budged in between 1990 and 2010. This period also corresponds to the stall in the gender convergence discussed by prominent academics like

${ }^{18}$ Kliff, Sarah. 2018. "A stunning chart shows the true cause of the gender wage gap." Vox.com. Available at https://www.vox.com/2018/2/19/17018380/gender-wage-gap-childcare-penalty Accessed 5/18/2021 
Paula England (2010) and Claudia Goldin (2014). Importantly, Goldin and others note that some of the observed convergence in the gender wage gap resulted not from a decline in occupational segregation, but rather from declines in blue collar wages (connected to the decline of unions among other things). In contrast, scholars have noted that the gender gap has persisted or increased in the most lucrative professions (like law and business) which differentially reward overwork, even as those professions have become less segregated. As a result, wages are now more equal at the bottom of the distribution than at the top (England et al 2020).

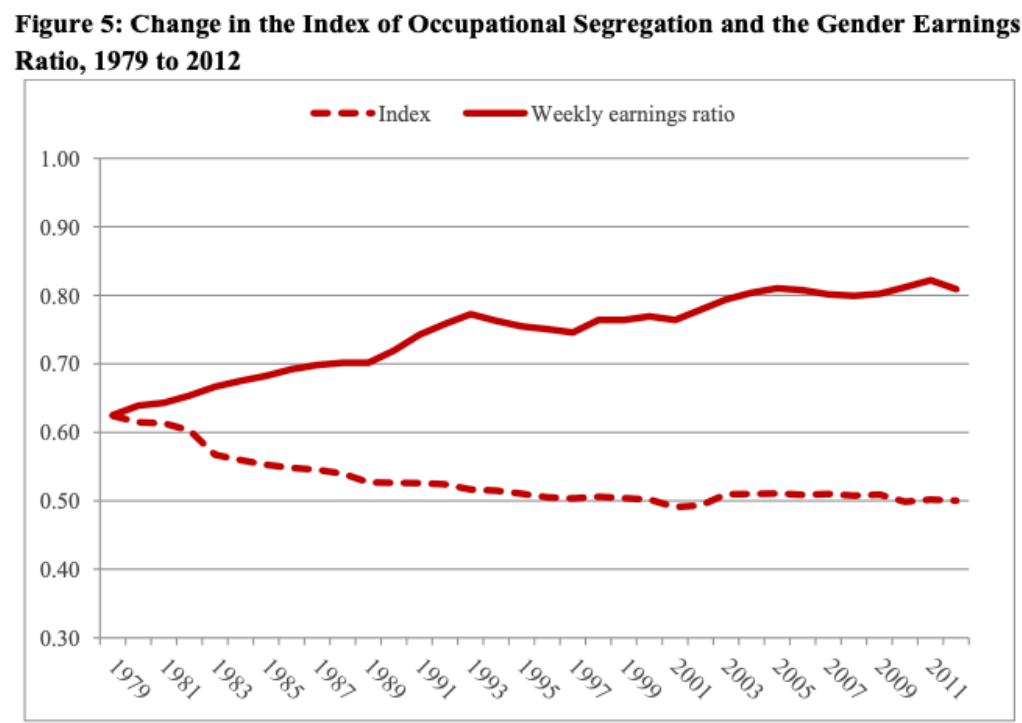

Figure 4: From Hegewisch and Hartmann 2014, p. 12.

Figures 5-7 show results from the hand-coded analysis of newspaper coverage of the gender wage gap. Figure 5 shows the centrality of the comparable worth movement to the conversation in the 1980s. At the movement's peak, about half of all coverage of the gender wage gap discussed comparable worth or pay equity. This period also saw a significant uptick in the amount of coverage, from about one article per year in the first half of the 1970s, to 31 articles in 1985 . The movement both put the gender wage gap on the public agenda, and also provided a narrative to understand it. Figure 6 shows how discussions of occupational segregation as an explanation for the gender wage gap fell with the comparable worth movement. Between 2000 and 2014, only 10$15 \%$ of articles about the gender wage gap discuss occupational segregation as a potential explanation. In contrast, Figure 7 demonstrates the persistence of narratives that emphasize women's choices as explanations for the gap (and the persistent absence of narratives foregrounding men's choices, which we coded for separately). Together, these data show how the gender wage gap has become relatively delinked in public conversations from occupational segregation (despite its centrality to researchers' understanding of the sources of the gap, and despite the persistence of occupational segregation itself) but has remained linked to discussions of women's choices around balancing work and family. This trend was epitomized by the publication of Sheryl Sandberg's (2013) Lean In: Women, Work, and the Will to Lead which emphasized the need for women to overcome internal barriers (such as unwillingness to speak up or negotiate). The book received extensive criticism from feminist scholars and activists as 
supporting a fundamentally misleading understanding of the structural problems women face, including researchers in psychology who found that lean in messaging can "lead to a preference for interventions focused on changing women rather than changing the system" (Kim et al 2018: 974).

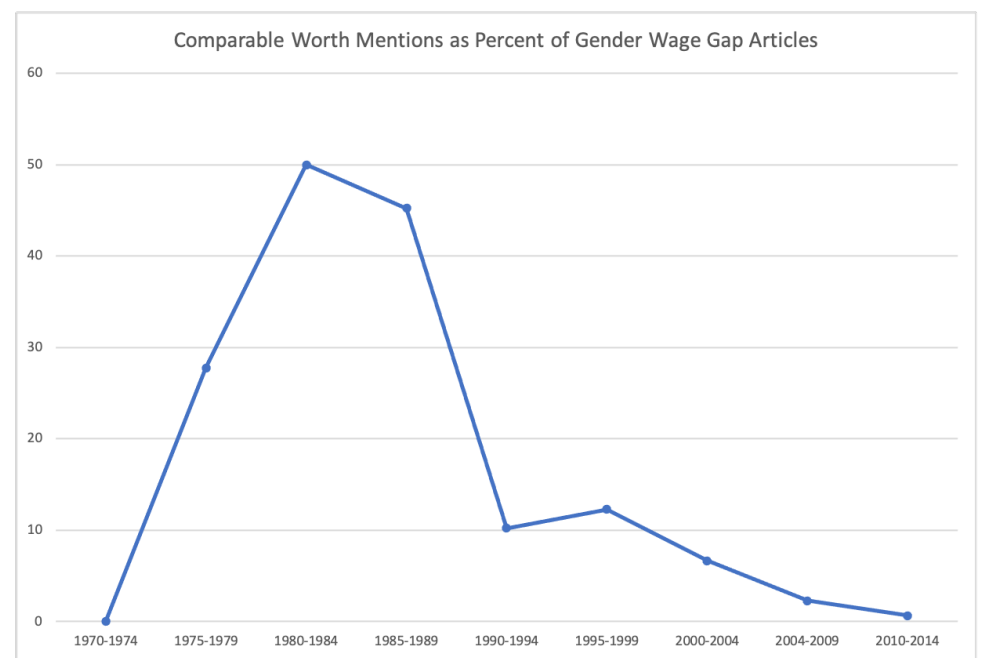

Figure 5: Percent of articles about the gender wage gap that mention comparable worth.

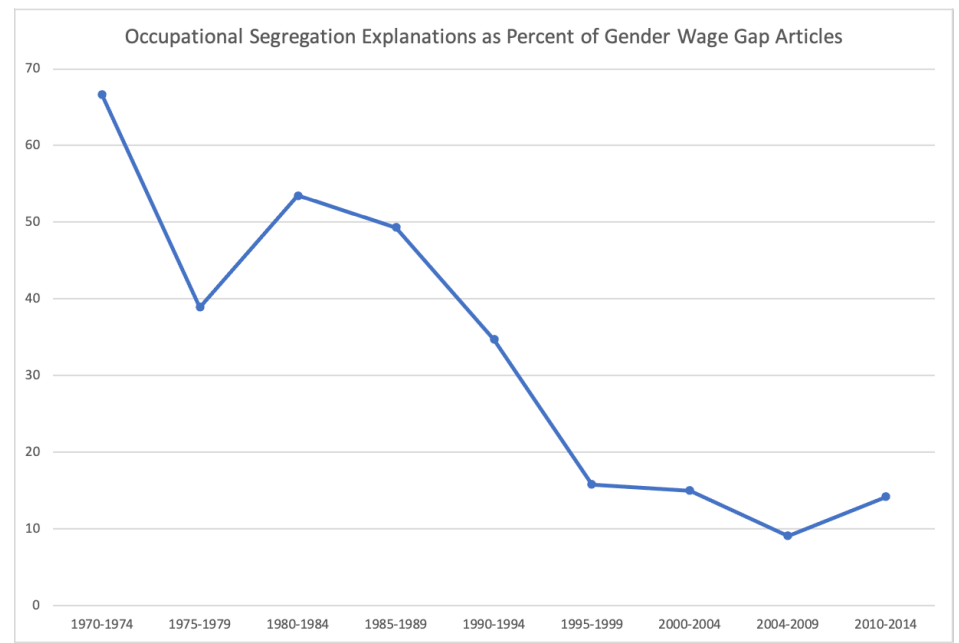

Figure 6: Percent of articles about the gender wage gap that mention occupational segregation as an explanation for that gap. 


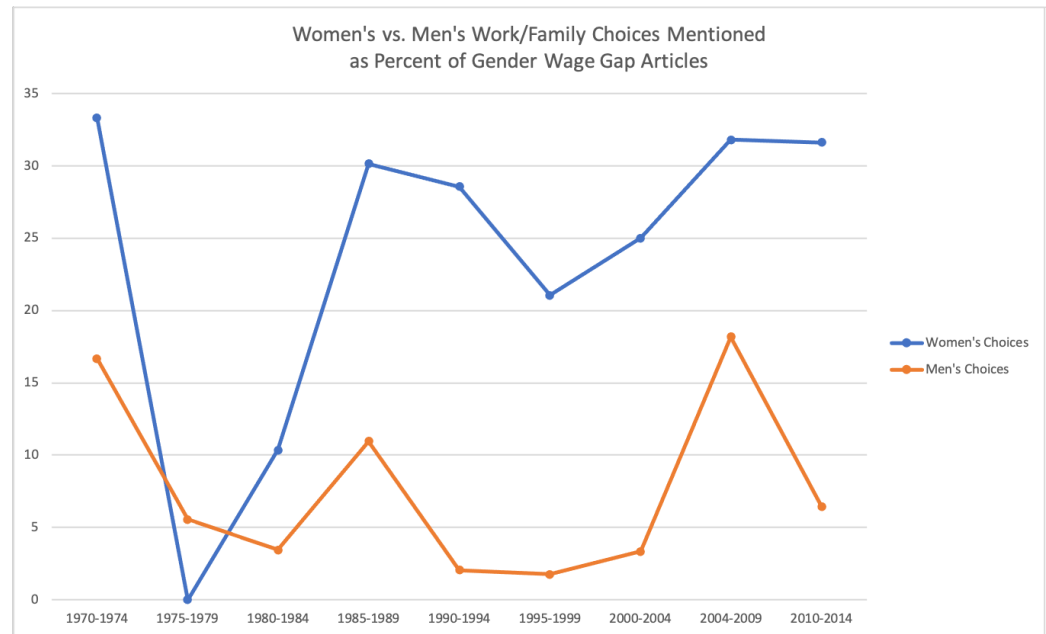

Figure 7: Percent of articles about the gender wage gap that mention women and men's choices about work and family as explanations for that gap.

Work-family conflicts are not the only persistent narrative in explanations for the gender wage gap. Explanations focusing on discrimination also occur at a steady clip. Figure 8 shows that throughout this period, discrimination is a prominent explanation, ranging from around $40 \%$ of articles to over $60 \%$ in some periods. Discrimination here includes both same-job different pay discrimination (made illegal by the Equal Pay Act), hiring, firing, and promotion discrimination (made illegal by the Civil Rights Act), and discrimination against women's occupations (that is, the kind of discrimination identified by comparable worth advocates, which remains legal in most states). These forms of discrimination were difficult to disentangle, as many articles referred to discrimination in a broad sense without specifying particular sites or mechanisms. Nonetheless, the persistence of discrimination messaging is important because it furthers one of the central dynamics in public discourse around the gender wage gap: the misunderstanding of the gap as one that captures solely same-job, different pay.

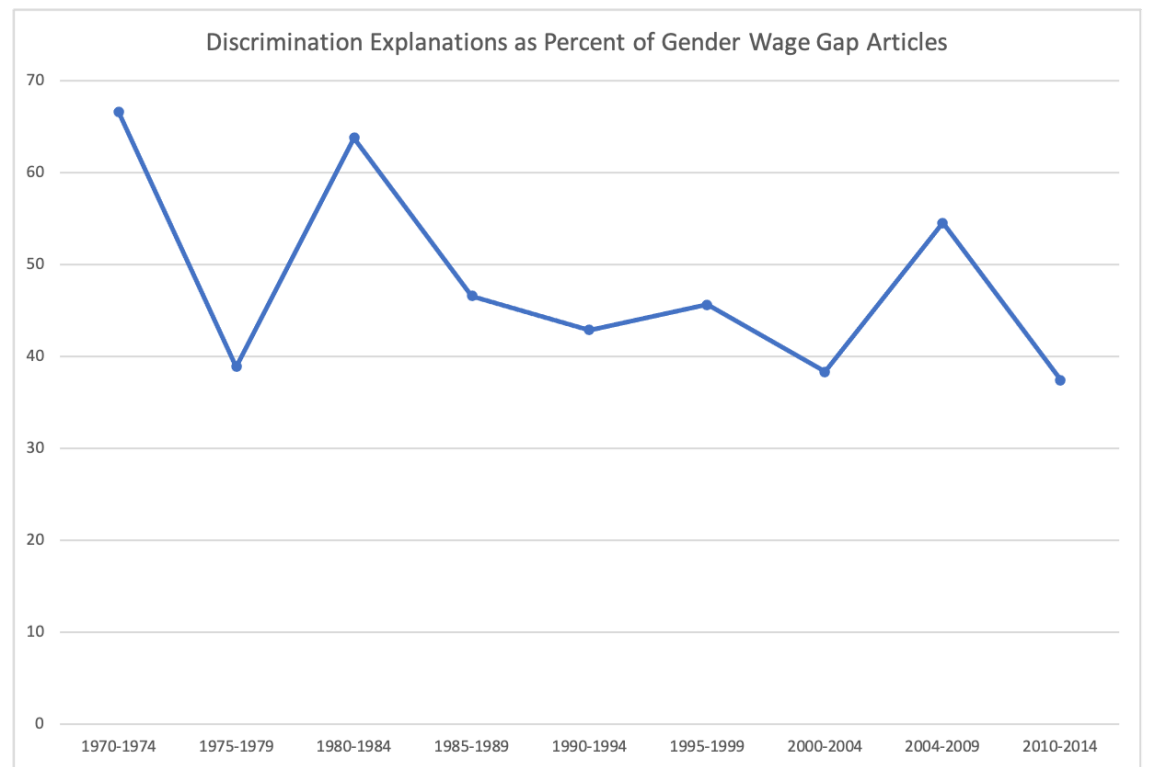

Figure 8: Percent of articles about the gender wage gap that mention discrimination as an explanation for that gap. 
For example, as early as 1974, when Time Magzine reported on the first ever Equal Pay Act Supreme Court case, they misreported the gender wage gap: "According to a recent Labor Department study of jobs, women who do work similar to men's earn 60c for every $1 \$$ earned by their male equals." 19 This sort of misunderstanding is pervasive to present. A recent example comes from a 2016 video starring actress Kristin Bell produced by Huffington Post for a series called "Celebs Have Issues" where Bell humorously argues that employers should engage in "pinksourcing" rather than outsourcing, replacing men with women working the same jobs and paying them just 77 cents on the dollar. ${ }^{20}$ In turn, this kind of misunderstanding from advocates of gender equality occasions a constant stream of debunking narratives. In this case, Karen Agness Lips wrote the rebuttal in Forbes, arguing that Bell's use of the gender wage gap - as well as many others, including those by then-presidential candidate Hillary Clinton - were misleading because they failed to account for "choices such as education level, years of experience, type of job, and hours worked."21 Here, Lips seizes on the inaccuracy of Bell's claims to assert that the wage gap can be accounted for by women's choices, categorizing education, hours, and type of job under that heading.

Similarly, the pay gap was constantly mobilized in debates over the Lily Ledbetter Fair Pay Act in 2009, and more recently around the Paycheck Fairness Act, both of which were aimed at making it easier to eliminate the disparities already made illegal by the Equal Pay Act - but which account for a tiny fraction of the remaining 18-20\% gap according to the consensus of researchers. For example, in a 2013 infographic circulated on twitter, Senator Kirsten Gillibrand linked the aggregate gender wage gap to the proposed Paycheck Fairness Act. This act would protect workers who share their salary information, and thus make it easier to detect illegal same-job, different pay discrimination. But that alone would not address most of the remaining gender wage gap, which derives from occupational segregation, the devaluation of women's work, and other factors not related to same-job, different pay discrimination.

\footnotetext{
19 Time Magazine. 1974. "Wages and Women." June 17. Page 90. Note this article was found separately from the systematically coded corpus.

${ }^{20}$ Available at https://www.youtube.com/watch?v=k_m5AlsQqcs accessed 9/19/2021.

${ }^{21}$ Agness Lips, Karen. 2016. "Another Celebrity Wrong On The Wage Gap." Available at https://www.forbes.com/sites/karinagness/2016/09/16/pinksourcing-is-the-latest-misleadingequal-pay-effort/ . Accessed 9/19/2021.
} 


\section{April 9, 2013 is Equal Pay Day}

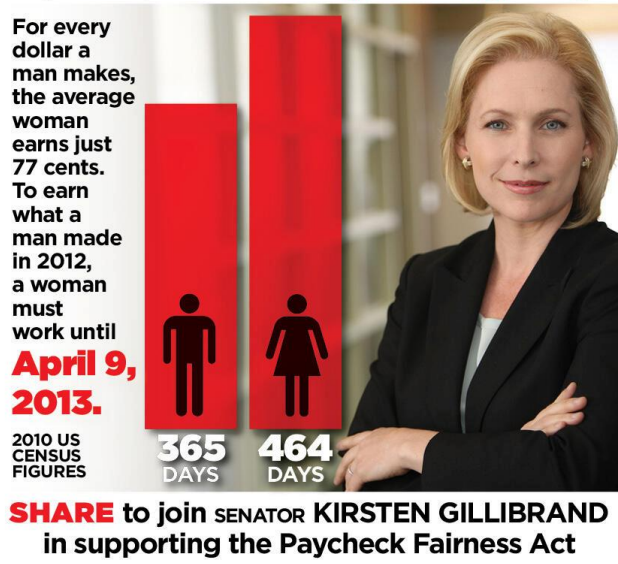

Figure 9: An infographic circulated by Senator Kirsten Gillibrand.

The centrality of illegal forms of discrimination to the folk interpretation of the gender wage gap constrains the ability of researchers to inform the public conversation (and perhaps results from past failures to do. In an oral history interview, sociologist Paula England put it like this:

And I would say, in my experience as a public speaker, and I'll include in this teaching it to undergraduates, explaining it to people at family dinners, talking to professionals, [EEOC], whatever. The hardest thing is that everybody thinks of sex discrimination as either hiring discrimination or lack of equal pay for equal work in the same job. [England Oral History Interview]

In turn, as we've seen above, conservatives call out these misunderstandings and use them to undermine the argument that remaining gender inequalities are a problem at all. Echoing the same arguments made conservatives back in the 1960s, contemporary conservative writers argue that the wage gap is a myth and misrepresentation because it does not control for various factors, and what's left after those controls entirely reflects women's choices.

This conversation persists in part because researchers are surprisingly unable to answer the central question of just how pervasive same-job, different-pay discrimination is. Employeremployee matched data are rare in the United States and none exist at a represenatative scale for the whole economy. For example, a recent paper by Smith-Doerr et al (2019) looks specifically at pay within jobs in the federal science agencies (like the NIH and NSF) precisely because they are a unique setting in which information about individuals' jobs, gender, and salary are all available. According to Smith-Doerr et al (2019: 542), theirs is just the fifth published paper using employeremployee matched data from multiple employers to examine gender wage gaps. This absence of a definitive exacerbates the popular (mis)understanding of the gender wage gap since academics cannot definitively say how much of the remaining gender gap does (or mostly doesn't) result from same-job, different-pay discrimination. Researchers are uniquely unable to answer the question that the public most wants to know. 


\section{Conclusion: Is the Gender Wage Gap a Good Description?}

The gender wage gap has become an ubiquitous indicator used to capture aggregate inequality. It is an object of academic study, an index used to rank nations, a frequent topic of public debate, and a site of partisan politics as liberals and conservatives vie to interpret the number's significance for proposed policies. Tracing the history of the gender wage gap from its emergence in post-war debates over working women, through the rise of human capital theory and neoclassical labor economics, to 1980s debates over comparable worth, up to the present conversation around work/family conflict and women's choices showcases a single statistic can travel in multiple domains at once.

The gender wage gap as stylized fact thus acts as a hinge (Abbott 2005) and boundary object (Star and Griesemer 1989). That is, the gap serves as a tool by which researchers and their findings can become relevant in public discourse, but also a site of persistent misunderstanding. The folk economics of the gender wage gap, absent the interpretive pressures of the 1960s-1980s feminist movements, instead invokes women's choices, filtered through the lens of legal consciousness. That is, the gender wage gap is often read as either a measure of illegal discrimination (which it is not), or as a benign reflection of women's unforced choices (which it is also not).

The gender wage gap is a particular and peculiar calculation. It is not obvious why this particular formulation won out as the stand-in for economic gender inequality. That it did so - that academics and commentators have spent so much energy on this number as opposed to others showcases the importance of the specific choices made in deciding how to describe economic life. The gender wage gap controls for full-time work, and little else. This choice - to center the conversation at this level - was highly productive for decades of social scientists who have parsed and accounted for the sources of that gap. At the same time, in a pattern familiar to scholars of technopolitics (see e.g. Hecht 1998), this technical choice must simultaneously be understand as an ethical or political one.

Thus, I end this article with a new question: Is the gender wage gap a good description? What even is a good description? Textbooks, handbooks, and seminars in the social sciences obsess over the question of what counts as a good causal claim. In contrast, description gets short shrift, often derided as "mere" or "just" description (see Gerring 2012). As a result, our collective capacity for evaluating the usefulness of descriptions is limited. Here, I offer some hints of how the history of the gender wage gap might inform that conversation, and how in turn we might evaluate the limits of the gap itself.

The gender wage gap is certainly useful - it coordinates academic attention, mobilizes movements, and permits consciousness raising by creating a kind of institutionalized awareness of persistent gender inequality. But it also enables confusion and a constant debunking narrative. Beyond that, its movements may not track what advocates of equality care about. For example, the gender wage gap stagnated in the 1970s, but that was an era of one of the biggest reductions in occupational segregation, and other gains which didn't manifest in the gender wage gap until the 1980s - by which point the backlash had started (Faludi 2016), and forces were in place that produced the stalled gender revolution by the 1990s (England 2010). And yet the 1980s saw some of the greatest reductions in the gender wage gap. In this sense, the gender wage gap lagged what 
it purported to measure. Beyond that, accounts of the gender wage gap highlight that a significant portion of the decline resulted from a relative fall in men's wages in blue-collar jobs. This decline in blue collar incomes may mechanically yield a reduction in the gender wage gap (given the persistence of occupational segregation), but it was not the kind of equality that feminists were and are fighting for (see Brady 1947). At a minimum, we must be careful to not treat the gender wage gap as either a direct reflection of same-job, different-pay discrimination (which it has never been), but also not to treat it as the unique indicator of economic gender equality. Perhaps then the problem is that we have asked too much of one number. Perhaps a good description must necessarily be one that views from multiple angles.

\section{References}

Abbott, Andrew. 2005. "Linked Ecologies: States and Universities as Environments for Professions." Sociological Theory 23(3):245-74.

Adler, Laura. 2020. "From the Job's Worth to the Person's Price: The Evolution of Pay-Setting Practices Since the 1950s." Working paper.

American Association of University Women (AAUW). 2020. "The Simple Truth About the Gender Pay Gap: 2020 Update." Available at https://www.aauw.org/app/uploads/2020/12/SimpleTruth 2.1.pdf . Accessed 5/18/2021.

Bergmann, Barbara R. 1974. "Occupational Segregation, Wages and Profits When Employers Discriminate by Race or Sex.” Eastern Economic Journal 1(2):103-10.

Beyer, Sylva. 1957. Spotlight on Women in the United States, 1956-1957. Women's Bureau of the Department of Labor.

Blau, Francine D., and Carol L. Jusenius. 1976. "Economists' Approaches to Sex Segregation in the Labor Market: An Appraisal.” Signs: Journal of Women in Culture and Society 1(3, Part 2):181-99.

Blaug, Mark. 1976. "The Empirical Status of Human Capital Theory: A Slightly Jaundiced Survey." Journal of Economic Literature 14(3):827-55.

Brady, Dorothy S. 1947. "Equal Pay for Women Workers." The Annals of the American Academy of Political and Social Science 251:53-60.

Buckley, John. 1971. "Pay Differences between Men and Women in the Same Job." Monthly Labor Review 94(11):36-40.

Chassonnery-Zaïgouche, Cléo. 2018. "Is Equal Pay Worth It?: Beatrice Potter Webb's, Millicent Garrett Fawcett's and Eleanor Rathbone's Changing Arguments.” Pp. 129-49 in The Routledge Handbook of the History of Women's Economic Thought. Routledge. 
Chassonnery-Zaïgouche, Cléo. 2020. "How Economists Entered the 'Numbers Game': Measuring Discrimination in the US Courtrooms, 1971-1989." Journal of the History of Economic Thought 42(2):229-59.

Chassonnery-Zaïgouche, Cléo, Beatrice Cherrier, and John D. Singleton. 2019. "“Economics Is Not a Man's Field': CSWEP and the First Gender Reckoning in Economics (1971-1991)." Available at SSRN 3510857.

Cobble, Dorothy Sue. 2004. The Other Women's Movement: Workplace Justice and Social Rights in Modern America. Princeton, N.J: Princeton University Press.

Cobble, Dorothy Sue, Linda Gordon, and Astrid Henry. 2014. Feminism Unfinished: A Short, Surprising History of American Women's Movements. W. W. Norton \& Company.

Congressional Record. 1962. July 25.

Darling, Martha. 1975. The Role of Women in the Economy. OECD.

Davies, Margery W. 1982. Woman's Place Is at the Typewriter: Office Work and Office Workers, 1870-1930. Philadelphia: Temple Univ Pr.

Dickinson, Z. Clark. 1943. "Men's and Women's Wages in the United States." International Labour Review 47(6):693-720.

Equal Employment Opportunity Commission (EEOC). 1980. 1980. Hearings before the United States Equal Employment Opportunity Commission on Job Segregation and Wage

Discrimination. Available at

https://babel.hathitrust.org/cgi/pt?id=mdp.39015005297109\&view=1 up\&seq =7

England, Paula. 1982. "The Failure of Human Capital Theory to Explain Occupational Sex Segregation." The Journal of Human Resources 17(3):358-70.

England, Paula. 2010. "The Gender Revolution: Uneven and Stalled.” Gender \& Society 24(2):149-66.

Ewick, Patricia, and Susan S. Silbey. 1998. The Common Place of Law: Stories from Everyday Life. University of Chicago Press.

Faludi, Susan. 2006. Backlash: The Undeclared War Against American Women. $15^{\text {th }}$ Anniversary Edition. Crown.

Gerring, John. 2012. “Mere Description.” British Journal of Political Science 42(04):721-46.

Goffman, Erving. 1977. "The Arrangement between the Sexes." Theory and Society 4(3):30131 . 
Goldin, Claudia. 1990. Understanding the Gender Gap: An Economic History of American Women. Oxford University Press.

Goldin, Claudia. 2014. "A Grand Gender Convergence: Its Last Chapter.” American Economic Review 104(4):1091-1119.

Hacking, Ian. 1983. Representing and Intervening: Introductory Topics in the Philosophy of Natural Science. First Edition. Cambridge University Press.

Hecht, Gabrielle. 1998. The Radiance of France: Nuclear Power and National Identity after World War II. The MIT Press.

Hegewisch, Ariane and Heidi Hartmann. 2014. "Occupational Segregation and the Gender Wage Gap: A Job Half Done." Institute for Women's Policy Research.

Hegewisch, Ariane and Adiam Tesfaselassie. 2020. "The Gender Wage Gap: 2020; Earnings Differences by Gender, Race, and Ethnicity." Institute for Women's Policy Research \#C495. Available at https://iwpr.org/wp-content/uploads/2020/09/Gender-Wage-Gap-Fact-Sheet-2.pdf .

Hirschman, Daniel. 2016. "Stylized Facts in the Social Sciences." Sociological Science 3:60426.

Hoff Sommers, Christina. 2014. "The Gender Wage Gap Myth.” American Enterprise Institute AEI. Retrieved May 18, 2021 (https://www.aei.org/articles/the-gender-wage-gap-myth/).

(House Hearings) "Equal Pay for Equal Work." 1962. Part 1. Hearings before the Select Subcommittee on labor of the Committee on Education and Labor. House of Representatives. $87^{\text {th }}$ Congress. Second Session. March 26-28.

Hower, Joseph E. 2020. “'You've Come a Long Way-Maybe': Working Women, Comparable Worth, and the Transformation of the American Labor Movement, 1964-1989." Journal of American History 107(3):658-84.

Howlett, Peter, and Mary S. Morgan. 2010. How Well Do Facts Travel?: The Dissemination of Reliable Knowledge. Cambridge University Press.

Hutner, Frances C. 1986. Equal Pay for Comparable Worth: The Working Woman's Issue of the Eighties. Praeger.

Kaldor, Nicholas. 1957. “A Model of Economic Growth.” The Economic Journal 67(268):591624.

Kelly, Erin, and Frank Dobbin. 1998. "How Affirmative Action Became Diversity Management: Employer Response to Antidiscrimination Law, 1961 to 1996." American Behavioral Scientist 41(7):960-84. doi: 10.1177/0002764298041007008. 
Kessler-Harris, Alice. 2001. In Pursuit of Equity: Women, Men, and the Quest for Economic Citizenship in 20th Century America. Oxford; New York: Oxford University Press.

Kessler-Harris, Alice. 2014. A Woman's Wage: Historical Meanings and Social Consequences. Updated Edition. The University Press of Kentucky.

Kim, Jae Yun, Gráinne Fitzsimons, and Aaron Kay. 2018. "Lean in Messages Increase Attributions of Women's Responsibility for Gender Inequality." Journal of Personality and Social Psychology 115:974-1001. doi: 10.1037/pspa0000129.

Klein, Viola. 1965. Women Workers: Working Hours and Services. OECD.

Krippner, Greta and Daniel Hirschman. 2021. "The Person of the Category: The Pricing of Risk and the Politics of Classification." Working paper.

Laughlin, Kathleen A. 2000. Women's Work and Public Policy: A History of the Women's Bureau, U.S. Department of Labor, 1945-1970. Northeastern University Press.

LeanIn.org. 2021. "Women are paid less than men — and that hits harder in an economic crisis." https://leanin.org/equal-pay-data-about-the-gender-pay-gap Accessed September 17, 2021.

Marini, Margaret Mooney. 1989. "Sex Differences in Earnings in the United States." Annual Review of Sociology 15(1):343-80.

McCann, Michael W. 1994. Rights at Work: Pay Equity Reform and the Politics of Legal Mobilization. University Of Chicago Press.

Mincer, Jacob, and Solomon Polachek. 1974. "Family Investments in Human Capital: Earnings of Women." Journal of Political Economy 82(2):S76-108.

NAS 1981 Women, Work and Wages: Equal Pay for Jobs of Equal Value

National Committee on Pay Equity (NCPE). 2021. "Equal Pay Day." Available at https://www.pay-equity.org/day.html . Accessed 5/18/2021.

National Research Council. 1981. Women, Work, and Wages: Equal Pay for Jobs of Equal Value. Washington, DC: The National Academies Press. https://doi.org/10.17226/91.

Nelson, Robert L., and William P. Bridges. 1999. Legalizing Gender Inequality: Courts, Markets and Unequal Pay for Women in America. Cambridge: Cambridge University Press.

Oaxaca, Ronald. 1973. "Male-Female Wage Differentials in Urban Labor Markets." International Economic Review 14(3):693-709. doi: 10.2307/2525981.

OECD. 2021. "Gender wage gap." Available at https://data.oecd.org/earnwage/gender-wagegap.htm . Accessed 5/18/2021. 
Pidgeon, Mary Elizabeth. 1937. Differences in the Earnings of Women and Men. Women's Bureau, Department of Labor.

Pullen, John. 2009. The Marginal Productivity Theory of Distribution: A Critical History. Routledge.

Sanborn, Henry. 1960. "Income Differences Between Men and Women in the United States." Ph.D., The University of Chicago, United States -- Illinois.

Sanborn, Henry. 1964. "Pay Differences between Men and Women." Industrial and Labor Relations Review 17(4):534-50.

Sawhill, Isabel V. 1973. "The Economics of Discrimination against Women: Some New Findings." The Journal of Human Resources 8(3):383-96. doi: 10.2307/144710.

(Senate Hearing) "Equal Pay Act of 1962." 1962. Subcommittee on Labor of the Committee on labor and Public Welfare. August 1.

(Senate Hearing) "Equal Pay Act of 1963." 1963. Subcommittee on Labor of the Committee on labor and Public Welfare. April 2, 3, 16.

Smith-Doerr, Laurel, Sharla Alegria, Kaye Husbands Fealing, Debra Fitzpatrick, and Donald Tomaskovic-Devey. 2019. "Gender Pay Gaps in U.S. Federal Science Agencies: An Organizational Approach.” American Journal of Sociology 125(2):534-76. doi: 10.1086/705514.

Swedberg, Richard. 2018. "Folk Economics and Its Role in Trump's Presidential Campaign: An Exploratory Study." Theory and Society 47(1):1-36.

Stafford, Frank. 1986. "Forestalling the Demise of Empirical Economics: The Role of Microdata in Labor Economics Research." Pp. 387-423 in Handbook of Labor Economics. Vol. Volume 1, edited by Orley C. Ashenfelter and Richard Layard. Elsevier.

Star, Susan Leigh, and James R. Griesemer. 1989. “Institutional Ecology, 'Translations' and Boundary Objects: Amateurs and Professionals in Berkeley's Museum of Vertebrate Zoology, 1907-39." Social Studies of Science 19(3):387-420.

Suter, Larry E., and Herman P. Miller. 1973. "Income Differences Between Men and Career Women.” American Journal of Sociology 78(4):962-74.

Swedberg, Richard. 2018. "Folk Economics and Its Role in Trump's Presidential Campaign: An Exploratory Study." Theory and Society 47(1):1-36. doi: 10.1007/s11186-018-9308-8.

Teixeira, Pedro N. 2007. Jacob Mincer: The Founding Father of Modern Labor Economics. Oxford University Press. 
Teixeira, Pedro N. 2014. "Gary Becker's Early Work on Human Capital - Collaborations and Distinctiveness." IZA Journal of Labor Economics 3(1):12. doi: 10.1186/s40172-014-0012-2.

Turk, Katherine. 2016. Equality on Trial: Gender and Rights in the Modern American Workplace. Philadelphia: University of Pennsylvania Press.

Williams, Joan C., Jessica Manvell, and Stephanie Bornstein. 2006. "Opt Out” or Pushed Out?: How the Press Covers Work/Family Conflict." The Center for WorkLife Law, UC Hastings.

Women's Bureau. 1975. Background Facts on Women Workers in the United States. Department of Labor.

Women's Bureau. 1976. The Earnings Gap Between Women and Men. Department of Labor.

Women's Bureau. 1979. The Earnings Gap Between Women and Men. Department of Labor. 